Open Access

\title{
Valuation method by regression analysis on real royalty-related data by using multiple input descriptors in royalty negotiations in Life Science area-focused on anticancer therapies
}

Jeong Hee Lee ${ }^{1}$, Bae Khee-Su${ }^{2}$, Joon Woo Lee ${ }^{3}$, Youngyong $\operatorname{In}^{4}$, Taehoon Kwon ${ }^{3^{*}}$ and Wangwoo Lee ${ }^{5}$

\footnotetext{
* Correspondence: kth78@kisti.re.kr

${ }^{3}$ Korea Institute of Science and

Technology Information (KISTI),

Hoegi-ro, 66, Dongdemun-gu, Seoul 130-741, South Korea

Full list of author information is

available at the end of the article
}

\begin{abstract}
Purpose: This research seeks to answer the basic question, "What would be the most determining factors if I perform regression analysis using several independent variables?" This paper suggests the way to estimate the proper royalty rate and up-front payment using multiple data I can get simply as input.

Design/methodology/approach: This research analyzes the dataset, including the royalty-related data like running royalty rate (back-end payments) and up-front payment (up-front fee + milestones), regarding drug candidates for specific drug class of anticancer by regression analysis. Then, the formula to predict royalty-related data is derived using the attrition rate for the corresponding development phase of the drug candidate for the license deal, TCT (Technology Cycle Time) median value for the IPC code (IP) of the IP, Market size of the technology, CAGR (Compound Annual Growth Rate) of the corresponding market and the revenue data of the license buyer (licensee).

Findings: For the anticancer (antineoplastics) drug classes, the formula to predict the royalty rate and up-front payment is as follows.

$<$ Drug Class: Anticancer activity candidates>

$$
\begin{aligned}
\text { Royalty Rate }= & 9.997+0.063 * \text { Attrition Rate }+1.655 \\
& * \text { Licensee Revenue }-0.410 * \text { TCT Median } \\
& -1.090 * \text { Market Size }-0.230 * \text { CAGR (Formula 1) }
\end{aligned}
$$

Up-Front Payment (Up-front + Milestones $)=2.909-0.006 *$ Attrition Rate $+0.306 *$ Licensee Revenue $-0.74 *$ TCT Median - $0.113 *$ Market Size $-0.009 *$ CAGR (Formula 2)

In the case of Equations Equation 1 to estimate the royalty rate, it is statistically meaningful at the significance level of $1 \%$ ( $P$-Value: 0.001); however, in the case of Equations Equation 2 to estimate the up-front payment it is statistically not meaningful ( $P$-Value: 0.288), thus requiring further study.

(Continued on next page)
\end{abstract}


(Continued from previous page)

Research limitations/implications (if applicable): This research is limited to the relationship between multiple input variables and royalty-related data in one drug class of anticancer (antineoplastics).

Practical implications (if applicable): Valuation for the drug candidate within a specific drug class can be possible, and the royalty rate can be a variable according to drug class and licensee revenue.

Keywords: Valuation, Licensing deal, Drug, Royalty data, Royalty rate, Up-front fee, Upfront Payment, Milestones, Regression, Drug class, Anticancer, Antineoplastics, Attrition rate, Development phase, Licensee, Life sciences, rNPV, eNPV (expected NPV), DCF, Multivariable analysis, IPC code, TCT median value, Market Size, CAGR, IP, Revenue, Multiple input descriptor, Significance level, P-Value, Prediction

\section{Introduction}

\section{R\&D productivity in life sciences and "fail fast, fail cheaply" strategy}

Drug development requires a great amount of time and money for each development phase. So drug development is expensive, time-consuming, complex, and risky (Lee et al. 2016). The global life sciences sector's general decline in $R \& D$ productivity is a frequent topic of conversation among industry stakeholders, investors, and analysts. Total projected value of late-stage pipelines for the 12 largest pharmaceutical companies showed a decline from $\$ 1,369$ billion to $\$ 913$ billion in 2013. The global life sciences sector in $R \& D$ productivity is generally declining. As the drug development costs and duration is bigger if the development phase is late phase, dropping the dug project in the early stage is cheaper. While there has been a decline in drug pipeline volumes and success rates in early-phase drug development, the number of stopped Phase III projects has also reduced gradually and the submission phase has posted a stable success rate. This is "fail fast, fail cheaply" strategy (Deloitte Centre for Health Solutions, 2015). As shown in Fig. 1, New drug and biologic approvals are not keeping pace with rising $R \& D$ costs (Kaitin, 2015). R\&D expenditures are constantly increasing, and the service enterprise is aiming to improve product development and the production process by increasing both internal and external R\&D activities (Kim, 2016).

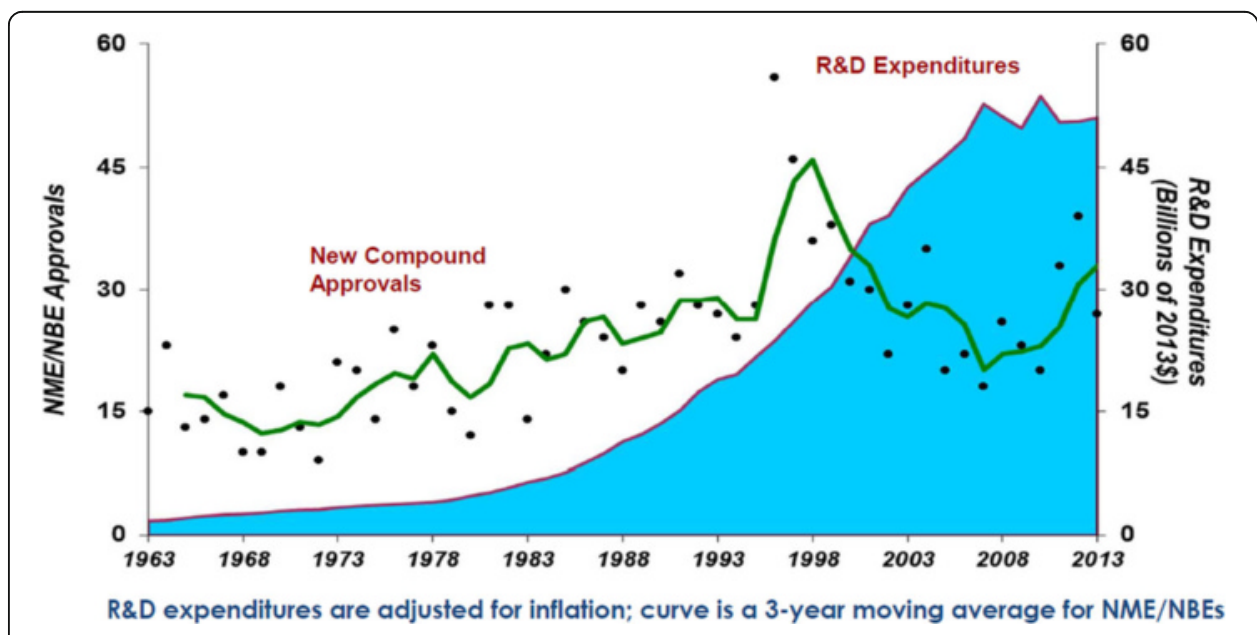

Fig. 1 New drug and biologics approvals and R\&D spending (DiMasi et al. 2016) 


\section{Licensing as good strategy}

Medtech R\&D spend is projected to grow by $4.2 \%$ annually, to $\$ 30.5$ billion by 2020 and Life sciences R\&D spending is projected to grow 2.4\% per year from 2013 to 2020, reaching $\$ 162$ billion. Some smaller biotech firms with limited R\&D budgets are securing financial support from large pharmaceutical companies through licensing and collaborative R\&D deals (Deloitte Centre for Health Solutions, 2015). With the recent collapse in the general and biotech equity issuance and IPO markets, biotech companies will have to turn more to partnering, licensing and M\&A for funding. Linkages of a firm can take in the form of a joint research project, joint development of a product, personnel exchanges, joint patenting, technology licensing, equipment purchase, and also a variety of other channels (Young, 2016; Patra \& Krishna, 2015). Licensing is a good strategy and business model to overcome financial difficulties due to long development period in life science. In many cases, purchasing a biotech firm is a more attractive option than buying the rights to the drugs the firm develops. Such a transaction can be a win for biotech firms, too, because large pharma companies typically possess the manufacturing facilities needed to commercialize drugs, which biotechs often lack. As shown in Fig. 2, Life sciences companies tallied over $\$ 300$ billion in completed or announced M\&A transactions globally for 2014 (Deloitte Centre for Health Solutions, 2015). Figure 3 illustrates the scale of licensing activity within the pharmaceutical industry in the last decade. More than 1,000 product deals (most of them licensing deals) were recorded each year in the PharmaDeals ${ }^{\oplus}$ v4 Agreements database since 2002 (Nigel Borshell \& Ahmed 2012).

\section{Demanding valuation in the licensing deal in the life sciences sector}

Pharmaceutical companies need to make up for their R\&D deficiencies with licensing activities. As soon as it comes to licensing and M\&A, companies are in urgent need of a valuation method that displays the correct value of early stage projects.

There are two major quantitative valuation approaches applied in the life sciences sector, DCF and real options. But even experienced licensing staff writhes to attribute the right value to a complex license contract and so the valuation is demanding. Compared to other industries, valuation in life sciences is more demanding due to the inherent complexity and length of R\&D. Main concerns are the choice of the right valuation

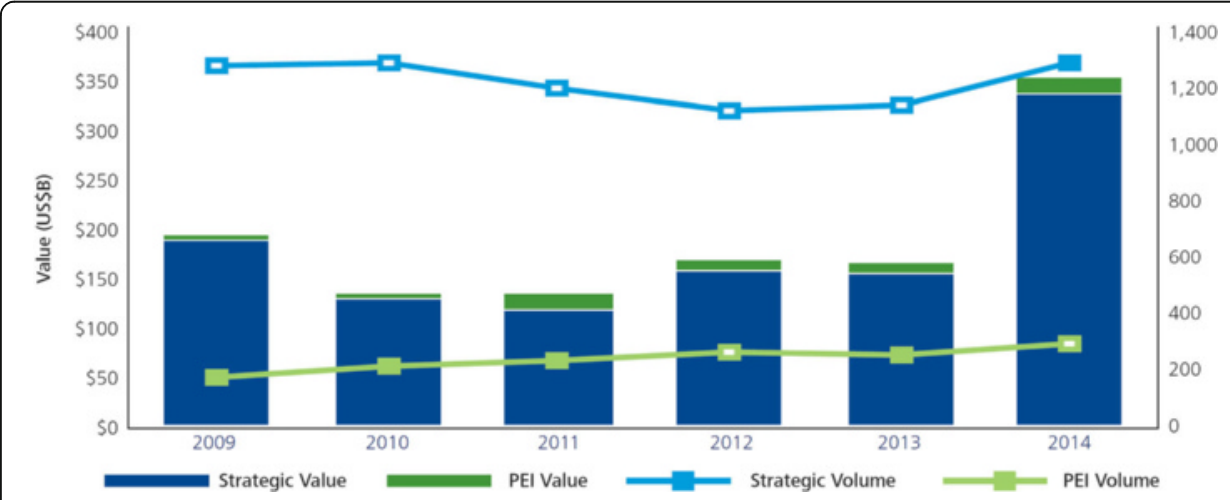

Fig. 2 Global life sciences M\&A (Deloitte Centre for Health Solutions, 2015) 


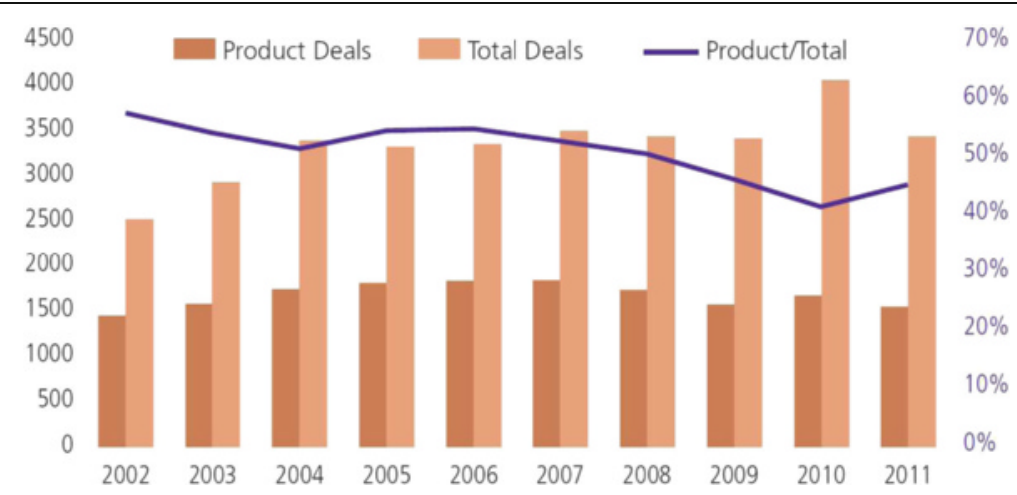

Fig. 3 Total licensing activity in the pharmaceutical industry for 10 years (Nigel Borshell \& Ahmed 2012)

method, the methodology itself, the input parameters and the interpretation of the results (Bogdan \& Villiger, 2010).

In reviewing the preceding research, there have been no cases where a regression analysis could be performed to estimate the proper royalty rate and up-front payment using the formula derived from the regression of the dataset of historical licensing data (Lee et al. 2016). This study suggests the way to estimate the proper royalty rate and up-front payment using multiple data descriptor we can get easily as input and can be used as a simple tool to answer the basic question, "What would be the most determining factors if I perform regression analysis using several independent variables?”

\section{Review of preceding research}

Lee et al. (2016)'s study was believed to be the first case to estimate the royalty rate and up-front payment using the formula derived from the regression of the dataset of historical licensing data, but further in-depth research is necessary for investigating the relationship between royalty-related data and more input descriptors such as market size, molecular and IP, Market size, licensee revenue, molecular structure, and IP can be converted to numerical value and can be used for the input for prediction (Lee et al. 2016) Fig. 4.

The value of technology depends on a large number of factors. As shown in Fig. 5, these include the target market size for the final therapeutic product, the anticipated clinical qualities of the drug and the extent of competition for the drug. These will include the phase specific success probabilities, development costs and timelines, the expected market size and market share, and the costs of goods, marketing and

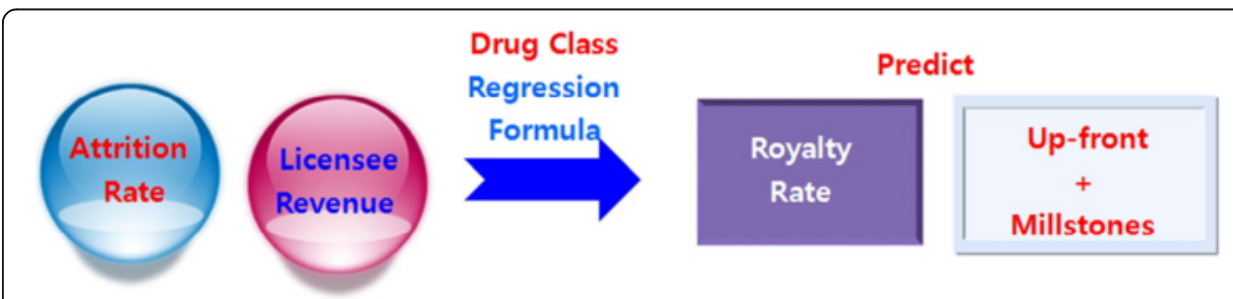

Fig. 4 The summary of estimation the royalty rate and up-front payment using the formula derived from the regression of the dataset of historical licensing data (Lee et al. 2016) 


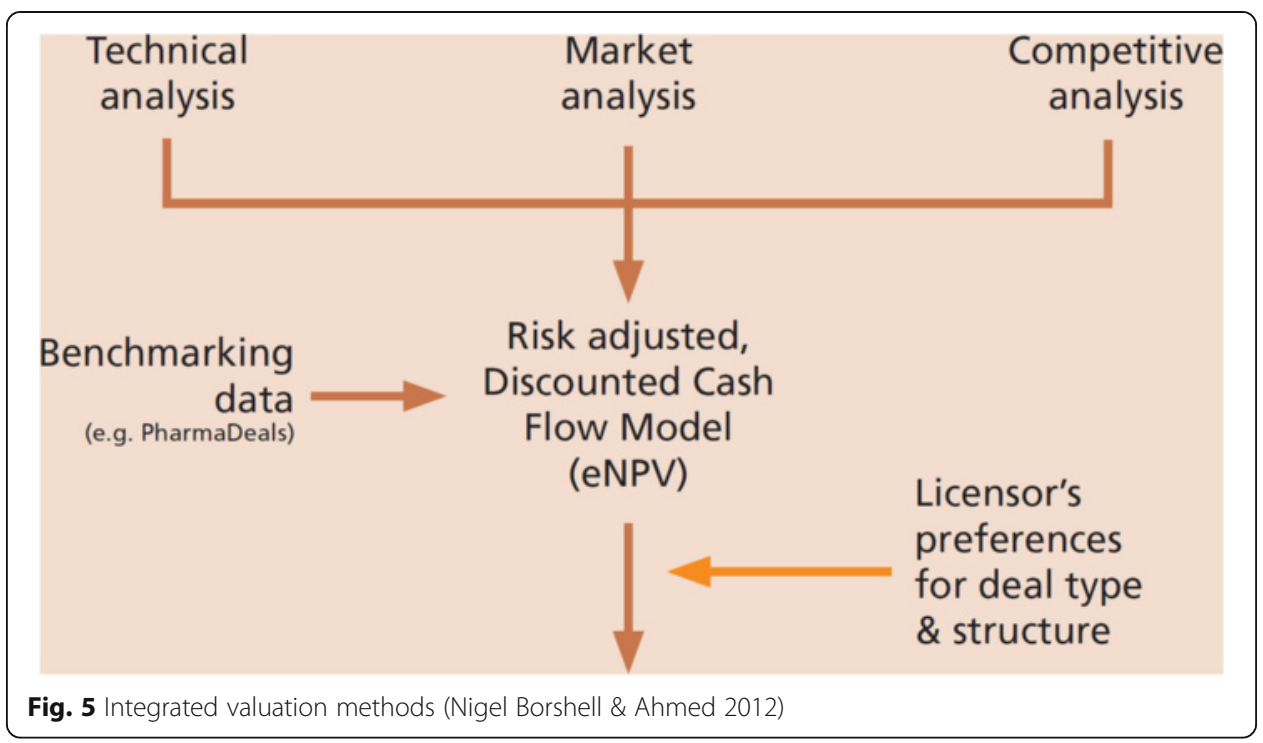

administration. Add to these the scenarios of product life cycle and commercial performance based on predicted ethical and/or generic competition and the task of calculating the value appears almost impossible (Nigel Borshell \& Ahmed 2012).

The most complex method conceptually to valuate is Monte Carlo simulation. Instead of putting in single point estimates of all the inputs to calculate a single value in a model, the Monte Carlo methodology puts in probability distributions for various inputs such as market size, costs, pricing and time to market, and then samples all those distributions to run multiple simulations, each calculating an NPV as shown in Fig. 6 (Pullan, 2014).

There was no perfect correlation between the market sizes of certain therapeutic areas and the market caps of early stage technology companies in the life sciences sector. According to Table 1, valuation of a given stem cell therapy company addressing

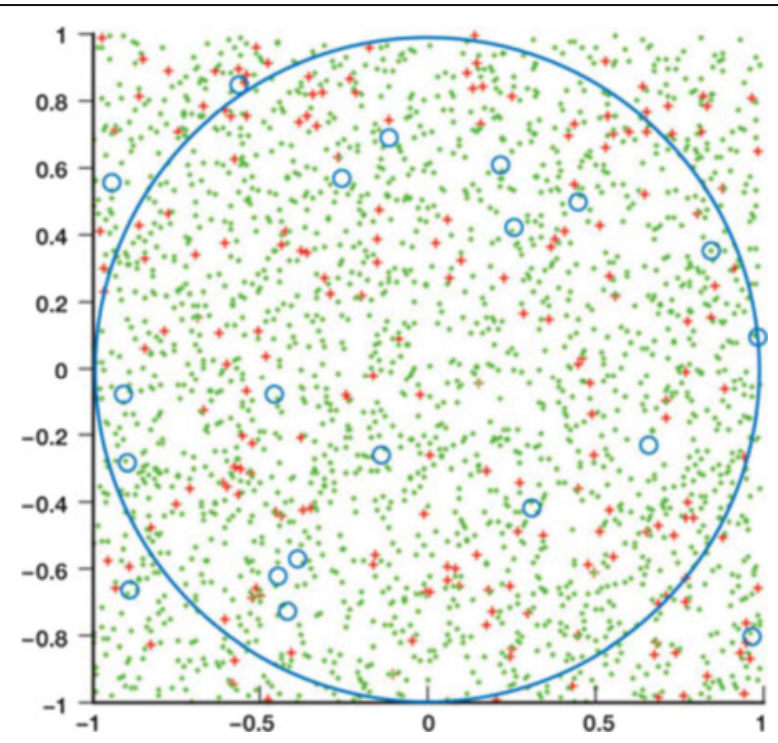

Fig. 6 Random points within a square to calculate pi 
Table 1 Early-stage technology companies

\begin{tabular}{lllll}
\hline Company & Technology & Disease area & R\&D status & Market capitalization \\
\hline StemCells & Cell therapy & Diabetes, Parkinson's & Preclinicals & \$55 million \\
Transition Therapeutics & Biopharma & Diabetes & Phase I & \$78 million \\
Alteon & Biopharma & Diabetes, Aging & Phase II, Preclinicals & \$69 million \\
Aradigm & Medical devices & Diabetes & Phase II, III & $\$ 134$ million \\
Aastrom Biosciences & Cell theraphy & Oncology, Dermatology & Phase I & $\$ 83$ million \\
Emisphere Technologies & Medical devices & Diabetes, Blood system & Phase I, II, III & \$109 million \\
NeoPharm & Biopharma & Oncology & Phase,I, II & \$476 million \\
ConjuChem & Biopharma & Deabetes, AIDS, CHF & Phase II & \$58 million \\
Spectrum Pharma & Biopharma & Oncology, Neurology & Preclinicals & \$79 million \\
Ergo Sciences & Biopharma & Diabetes & Technology sold & \$15 million \\
\hline
\end{tabular}

diabetes appears to be very low. This could be due to conservative assumptions; a market premium for track record and proven capability of the listed companies; key collaborative alliances; and positive news during the product development stage. Given these factors, valuation assumptions also depend on the purpose of the valuation and who is represented in the exercise (Ranade, 2008).

Patents and patent valuation have raised tremendous concerns from the researchbased pharmaceutical industry for a long time. It is demonstrated that PTDI (Pharmaceutical technology details indicators) like NCE actually have significant influence on patent value and, more significantly, enhance the quality of existing valuation methods. NCE actually plays the role of the strongest positive factor influencing the expected patent value. On the contrary, $\mathrm{OD}$ (Orphan Drug) and $\mathrm{PD}$ (Pediatric Drug) show significantly negative effects, which could be rationally explained by the small patient population for these drugs (Hu et al. 2008) Table 2.

Table 2 The expected effect on patent value according to pharmaceutical industry related factors

\begin{tabular}{|c|c|c|c|}
\hline Variable & Definition & Expected effect on Patent value & Date source \\
\hline CRECEIVE & Number of citations received & + & NBER \\
\hline OPPOSITION & The occurrence of opposition (1:yes; 0: no) & + & INPADOC \\
\hline CLAIMS & Number of claims & + & NBER \\
\hline CMADE & Number of citations mode & + & NBER \\
\hline BLOCKBUSTER & Blocbuster drug (1:yes; 0: no) & + & PHARMADL \\
\hline PORTFOLIO & Number of patents in a patent portfolio & + & FDA \\
\hline NDS & New dosing schedule (1:yes; 0: no) & Unknown & FDA \\
\hline $\mathrm{NI}$ & New indication (1:yes; 0: no) & Unknown & FDA \\
\hline NC & New combination (1:yes; 0: no) & + & FDA \\
\hline NCE & New chemical entity (1:yes; 0: no) & + & FDA \\
\hline NDF & New dosage form (1:yes; 0 : no) & + & FDA \\
\hline NP & New product (1:yes; 0: no) & + & FDA \\
\hline NS & New strength (1:yes; 0: no) & Unknown & FDA \\
\hline OD & Orphan drug (1:yes; 0: no) & - & FDA \\
\hline PD & Pediatric drug (1:yes; 0: no) & - & FDA \\
\hline GYEAR & Grant year & - & NBER \\
\hline
\end{tabular}

NBER US National Bureau of Economic Research, INDAPOC International Patent Documentation Center, PHARMADL Pharmaceutical Digital Library 
There was a simulation approach to value patents and patent-protected R\&D projects based on the Real Options approach and takes into account uncertainty in the cost to completion of the project, uncertainty in the cash flows to be generated from the project, and the possibility of catastrophic events that could put an end to the effort before it is completed. Figure 7 shows the critical cash flows rates (critical costs) for costs between $\$ 80$ and $\$ 100$ million (cash flow rates between $\$ 9$ and $\$ 18$ million) (Schwartz, 2004). Since Eduardo Schwartz's paper, patent valuation has increasingly attracted considerable interest of researchers and practitioners. Nevertheless, few of the firms that can benefit from patent valuation have the capability to perform in-house patent valuation, and even the patent valuation expertise of consultancies and financial institutions seems limited (Carte, 2005; Ernst et al. 2010).

Thus, at present, there are problems and challenging issues for the research on patent valuation. First, among previous studies that provide the excellent overviews about the determinants (indexes) of patent, it was shown that forward citations are significantly correlated with a patent's market value (Nair et al. 2012). Forward citations are defined in $\mathrm{Hu}$, Rousseau, \& Chen's study as the number of patent citations that an auctioned patent received till the Ocean Tomo date of sale. However, measuring a patent's market value by simply counting the patent's forward citations has limitation to reflect the complexity in the networks of patents. Moreover, previous studies have shown that the structural patent indicators of the patent citation networks ( $\mathrm{PCNs}$ ) are correlated with patent value and the correlations are different among the groups of firms ( $\mathrm{Hu}$ et al. 2012). PCNs are constructed by setting patents as nodes and their citation information as edges. Nevertheless, few efforts have been made to investigate the effect of structural patent indicators in forward citations on patent price. Second, it is difficult to investigate dynamics between patent indicators and patent price because the actual price at which the patent is sold or licensed is often a privately maintained record. To resolve these problems and challenging issues, the paper proposed a systematic approach, which investigates the effect of the structural patent indicators, extracted from forward citations, on patent price from the relationship with firm market value. To explain, first, the paper introduces the forward patent citation networks (FPCNs), from which the structural patent indicators are extracted as a set of features to represent patent price.

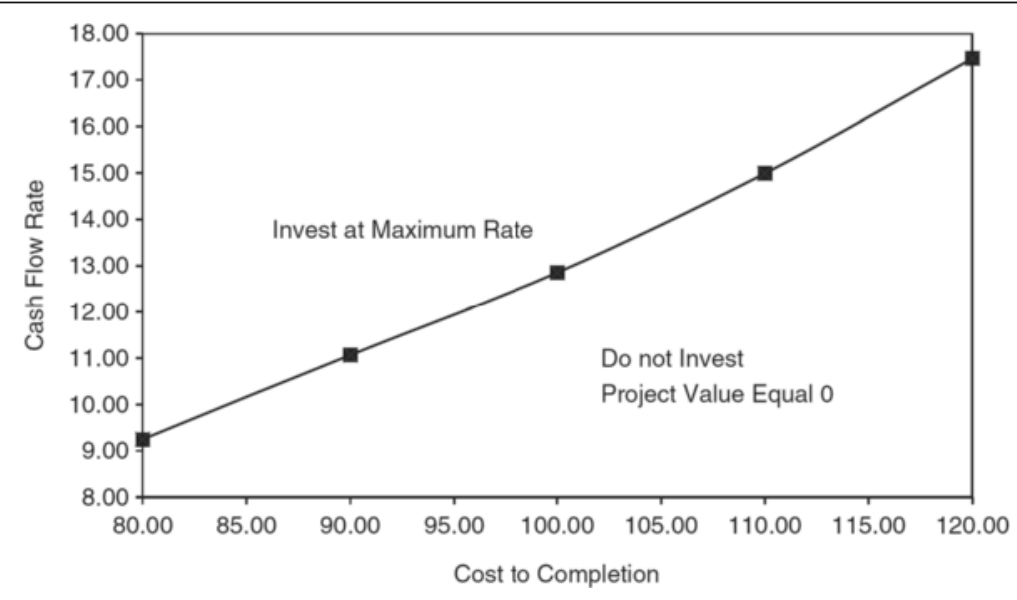

Fig. 7 Critical values for investment 
Thereafter, the panel data econometric approach is applied to examine the relationship between the firm-level structural patent indicators and enterprise value (EV), selected as firm market value. Finally, dynamics between the structural patent indicators in the FPCNs and patent price are explored by referring to the discovered relationship (Suh, 2015) Fig. 8.

\section{Research design and scope and limitation}

\section{Research design}

This research analyzes the anticancer (antineoplastics) dataset, including the royaltyrelated data like running royalty rate and up-front payment, regarding drug candidates for specific drug class of anticancer, by regression analysis between royalty-related data and multiple input descriptors like the attrition rate for the development phase, market size, TCT median value for the IPC code (IP) of the patent, and the revenue data of the license buyer for deriving the formula to predict royalty-related data.

According to the preceding research, the main factors to drive the size of licensing deals in the life sciences area are development phase, drug class, contract type, contract scope, licensee, molecular structure, market, strategies, competition, IP, and novelty (Arnold et al. 2002). Market size, licensee revenue, molecular structure, and IP can be converted to numerical value and can be used for the input for prediction for royaltyrelated data such as running royalty rate (back-end payments) and up-front payment (up-front fee + milestones). In the case of molecular structure, it requires professional chemical software to convert chemical structure into numeric code and requires the collection of molecular structure information for the drug candidate. This study selected the attrition rate for the development phase, market size, CAGR, TCT median

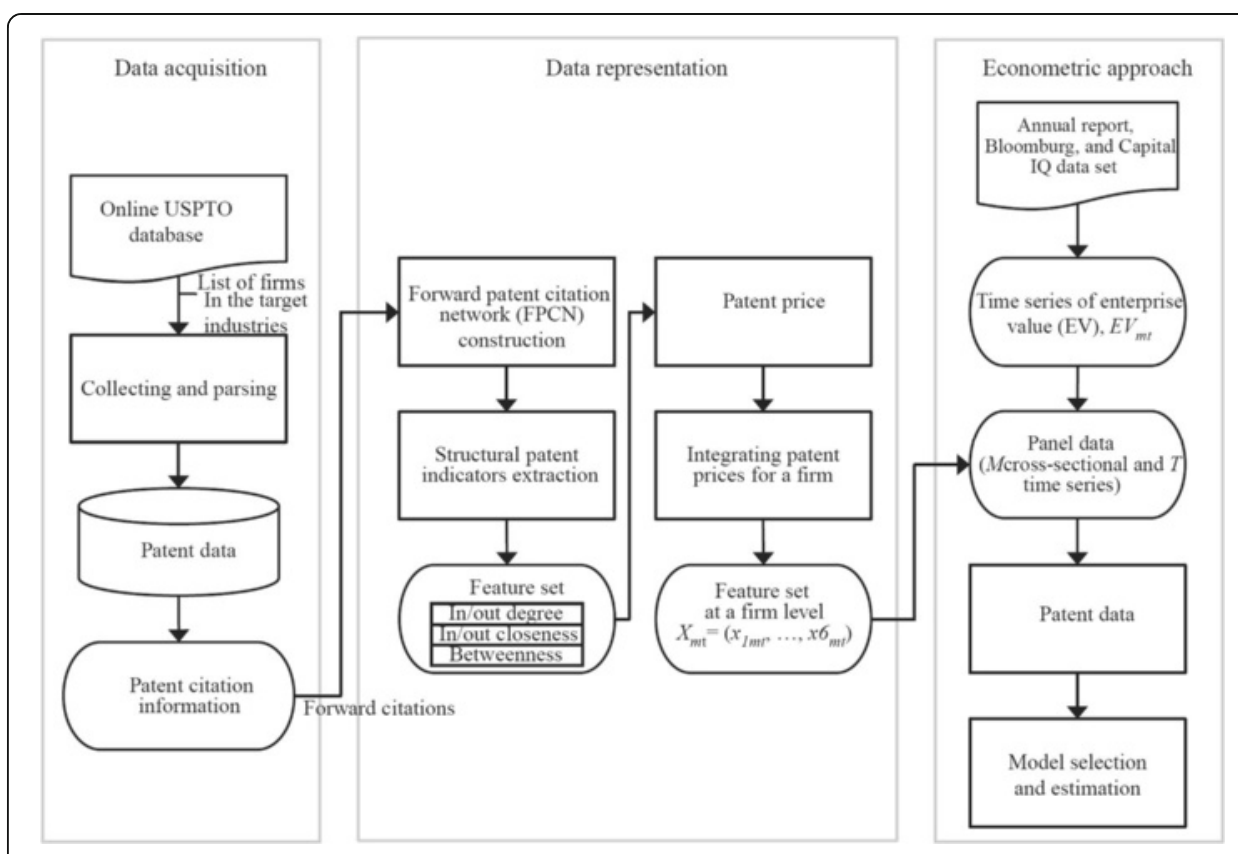

Fig. 8 The research framework to study the effect of the structural patent indicators on patent price (Suh, 2015) 
value for the IPC code (IP), and the revenue data of the license buyer as descriptors for input $\mathrm{x}$-axis of regression.

The main research procedure is divided into three steps as shown in Fig. 9: data collection, Preparation of dataset, and regression analysis.

Step 1. Collection of data such as the running royalty rate, up-front fee, milestones, licensor, licensee, the revenue of licensee, the corresponding drug subclass, IPC subclass, TCT median value of the patent, market size, and CAGR of the drug subclass, and the development phase in drug licensing deals

This study collected the data for one drug class of anticancer. Data collection is based on the several resources described in our previous study (Lee et al. 2016). Additional resources are: (1) Site for checking the revenue of Licensee: http://www.google.com/finance and http://finance.yahoo.com/; (2) Site to retrieve the market size and CAGR of the corresponding drug subclass: http://www.giikorea.co.kr/ (3) Site for checking the IPC subclass of the patent: www.google.com/patents.

\section{Step 2. Preparation of dataset ready for regression analysis}

The procedure and examples of data normalization of up-front payment (up-front fee + milestones) and back-end payment (running royalty rate) to prepare the dataset ready for regression are described in our previous paper (Lee et al. 2016).

The procedure to get TCT median Value is divided into three steps as shown in Fig. 10: Patent Navigation, Getting IPC Subclass from the patent, and Getting Technology Cycle Time Median Value.

Figures 11 and 12 show the example to get IPC Subclass from the patent, and to get TCT Median Value (Average) from IPC subclass.

The procedure to get Market size (2015) and CAGR (\%) is divided into three steps as shown in Fig. 13: Navigate market information, Convert the currency unit of the market size to million dollar, and Estimate the market size of year 2015 by applying CAGR.

Figure 14 shows the example to get the market size of year 2015 and CAGR (\%).

Step 3. Regression analysis to investigate the relationship between multiple independent variables of the attrition rate for the development phase, market size, CAGR, TCT median value for the IPC code (IP), and the revenue data of the license buyer and the dependent variable of up-front payment (up-front fee + milestones) and the relationship between multiple independent variables of the attrition rate for the development phase, market size, CAGR, TCT median value for the IPC code (IP), and the revenue data of the license buyer and the dependent variable of back-end payment (running royalty rate)

Used software: IBM SPSSS Statistics Version 21

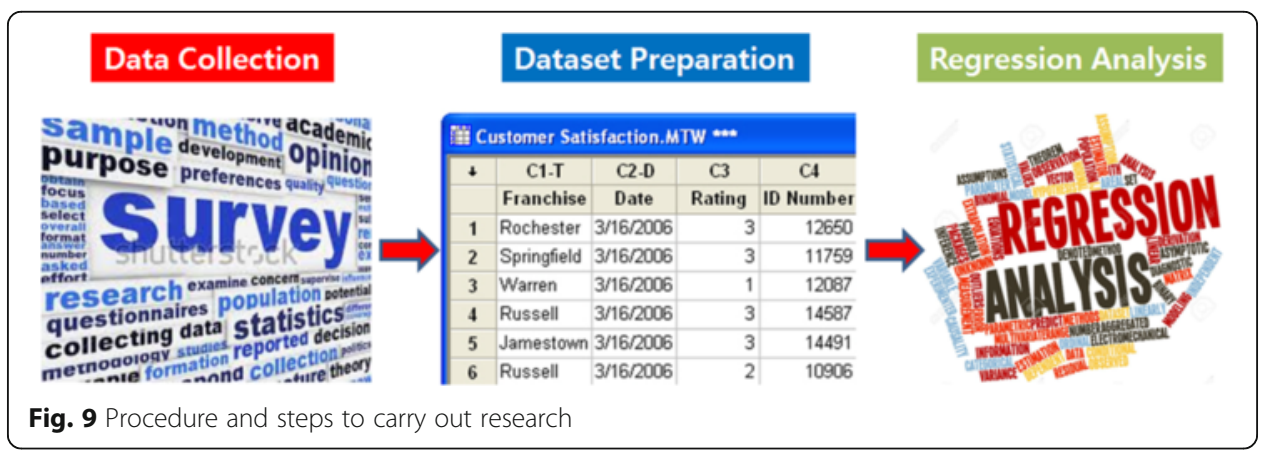




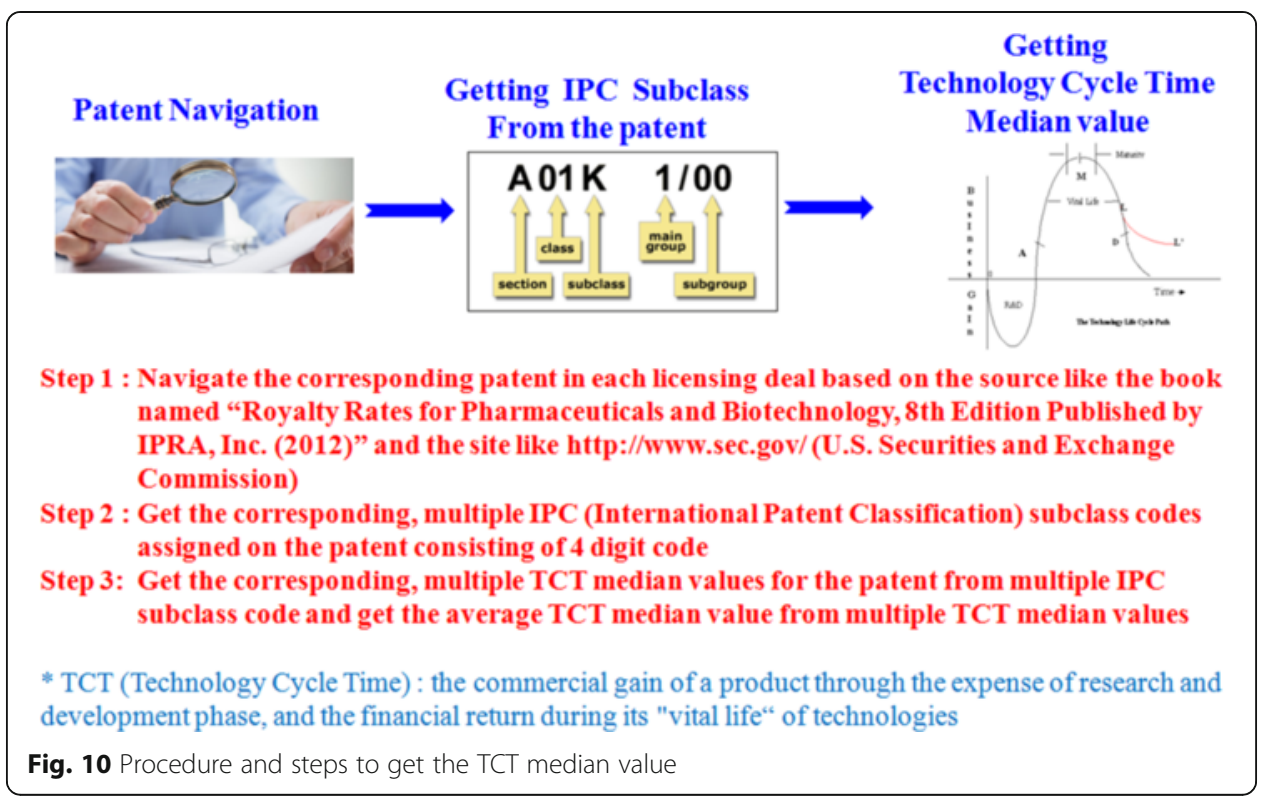

Regression 1: $\mathrm{X}$-axis = multiple independent variables of the attrition rate for the development

phase, market size, CAGR, TCT median value for the IPC code (IP), and the revenue data of the license buyer

Y-axis = up-front payment (up-front fee + milestones) [Unit: USD]

Regression 2: $\mathrm{X}$-axis = multiple independent variables of the attrition rate for the development

phase, market size, CAGR, TCT median value for the IPC code (IP), and the revenue data of the license buyer

Y-axis = back-end payment (running royalty rate) [Unit: USD]

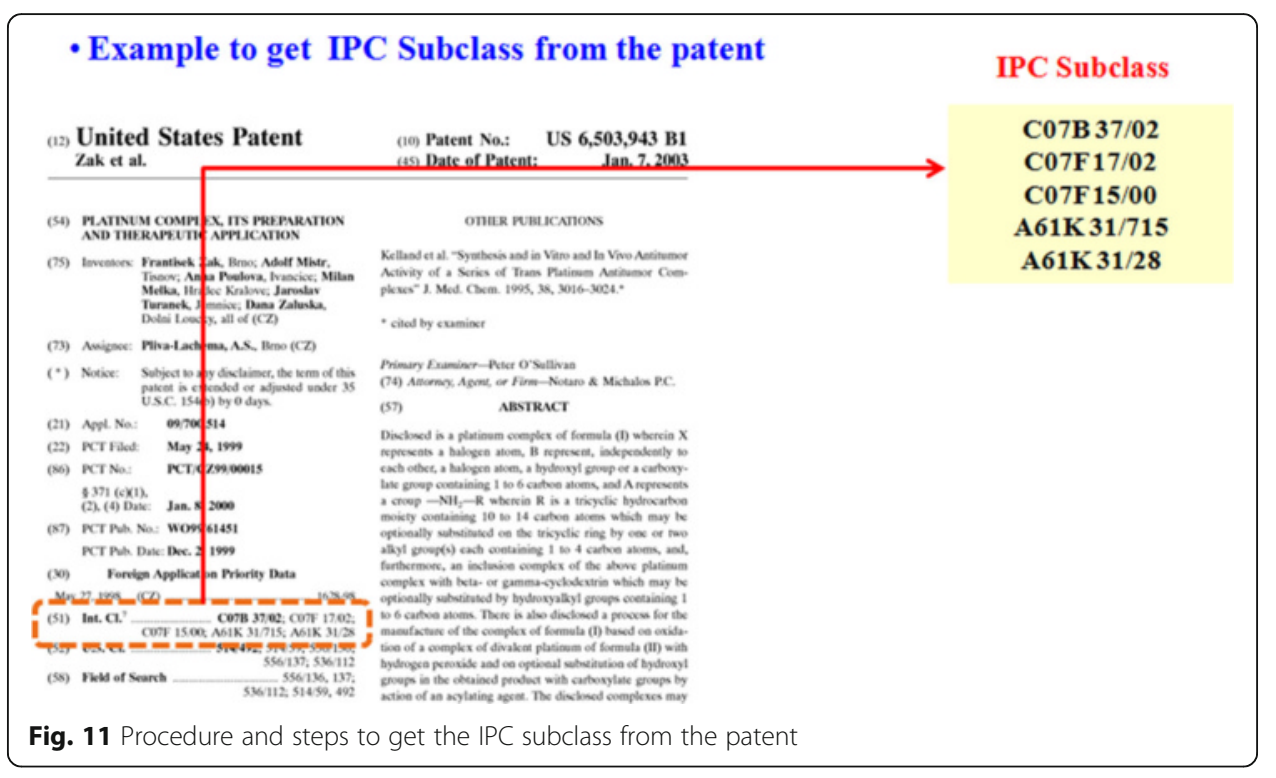




\begin{tabular}{|c|c|c|}
\hline \multicolumn{2}{|c|}{ Example to get } & TCT Median Value (Average) \\
\hline IPC & Subclass contents & $\begin{array}{c}\text { TCT median } \\
\text { value (Year) }\end{array}$ \\
\hline A61K & PREPARATIONS FOR MEDICAL, DENTAL, OR TOILET PURPOSES & 8 \\
\hline C07B & $\begin{array}{c}\text { GENERAL METHODS OF ORGANIC CHEMISTRY; APPARATUS THEREFOR } \\
\text { COTF }\end{array}$ & 4 \\
\hline $\begin{array}{l}\text { ACYCLC, CARBOCYCLIC, OR HETEROCYCLIC COMPOUNDS CONTAINING ELEMENT } \\
\text { SOTHER THAN CARBON, HYDROGEN, HALOGEN, OXYGEN, NITROGEN, SULFUR, SE } \\
\text { LENIUM OR TELLURIUM }\end{array}$ & 7 \\
\hline
\end{tabular}

Ref) Tectnology Valuation Practice Guide, Ministry of Trade, Industry and Energy oe Korea (December 2014)

\begin{tabular}{|c|c|c|}
\hline IPC Subclass & TCT Median & TCT Median (Average) \\
\hline $\begin{array}{l}\text { C07B 37/02 } \\
\text { C07F 17/02 }\end{array}$ & $\begin{array}{l}4 \text { year } \\
7 \text { year }\end{array}$ & $\begin{array}{c}(4+7+7+8+8) / 5 \\
=6.8 \text { year }\end{array}$ \\
\hline C07F 15/00 & 7 year & \\
\hline A61K 31/715 & 8 year & \\
\hline A61K 31/28 & 8 year & \\
\hline
\end{tabular}

Fig. 12 Example to get the TCT median value (average) from the IPC subclass

\section{Scope and limitation of research}

The scope of this research is to derive the formula to predict royalty-related data, such as running royalty rate (back-end payments) and up-front payment (up-front fee + milestones), using the attrition rate for the corresponding development phase of the drug candidate for the anticancer (antineoplastics) drug class and the revenue data of the license buyer (licensee). Statistically speaking, this research derives the formula to predict royaltyrelated data using multiple independent variables like the attrition rate for the development phase, market size, CAGR, TCT median value for the IPC code (IP), and the revenue data of the license buyer. Also, this research selected the attrition rate for the development phase, market size, CAGR, TCT median value for the IPC code (IP), and the revenue data of the license buyer as descriptors for the input for the X-axis of regression. This study is limited to the relationship between one drug class of anticancer (antineoplastics) and royalty-related data. For further studies, we will cover more detail the relationship for more drug classes using multiple input descriptors and we will cover the comparison of the estimation results between by using the prediction formula derived regression analysis Vs. by using traditional valuation methods like e-NPV or Real Options.

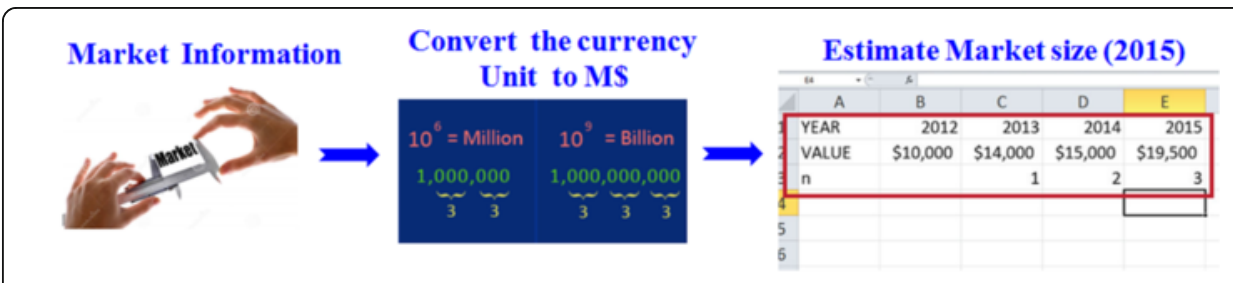

Step 1 : Navigate the market information including the market size and CAGR (Compound Annual Growth Rate) that the drug subclass is belonging to from several sources like the site of google, reports, association materials, academy materials and so on

Step 2 : Covert \& unify the unit of market size to Million dollar (MS)

Step 3 : Get the market size of year 2015 by applying CAGR to the market size described in the data source

Fig. 13 Procedure and steps to get the market size (2015) and CAGR (\%) 


\section{- Example to get Market (2015) and CAGR (\%)}

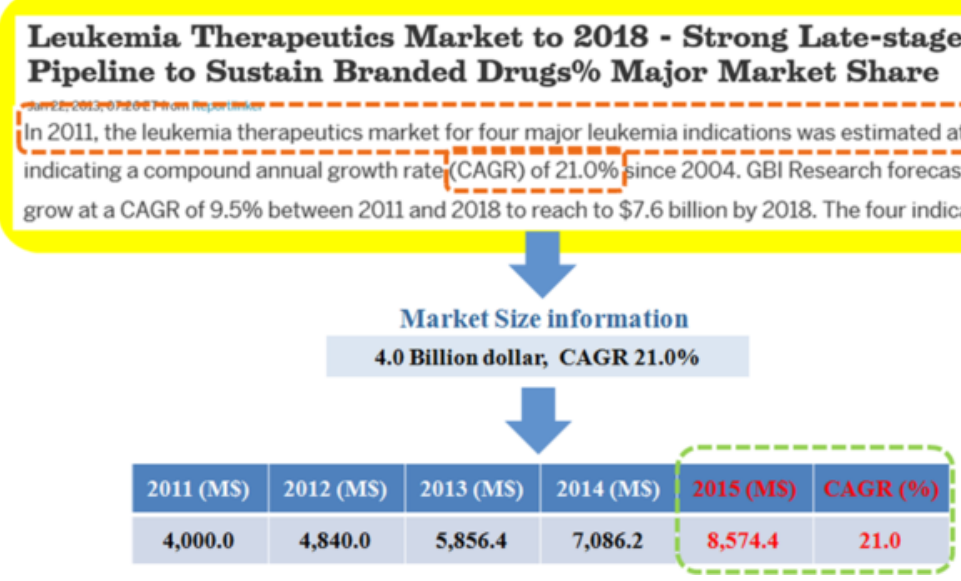

Fig. 14 Example to get the market (2015) and CAGR (\%)

\section{Analysis of dataset}

\section{Analysis of anticancer (antineoplastics) dataset}

Figures 15 and 16 show the analysis result of the drug subclass of Anticancer dataset. As shown in Fig. 15, top 3 ranking in the frequency hit percent of drug subclass is as follows: (1) Cancer Immunotherapies, Lung Cancer (2) Leukemia Therapeutics, Protein Kinase Inhibitor Antineoplastics (3) Breast Cancer, Drug Delivery System, Hematologic malignancies, Liver Cancer, Monoclonal Antibody Antineoplastics, Pancreatic Cancer.

Figure 17 shows the analysis result of IPC code in the corresponding patent in the licensing deal of anticancer drug dataset. As shown in Fig. 17, top 5 ranking in the frequency hit percent of IPC Code is as follows: (1) PREPARATIONS FOR MEDICAL, DENTAL, OR TOILET PURPOSES (A61K) (2) HETEROCYCLIC COMPOUNDS (C07D) (3) SPECIFIC THERAPEUTIC ACTIVITY OF CHEMICAL COMPOUNDS

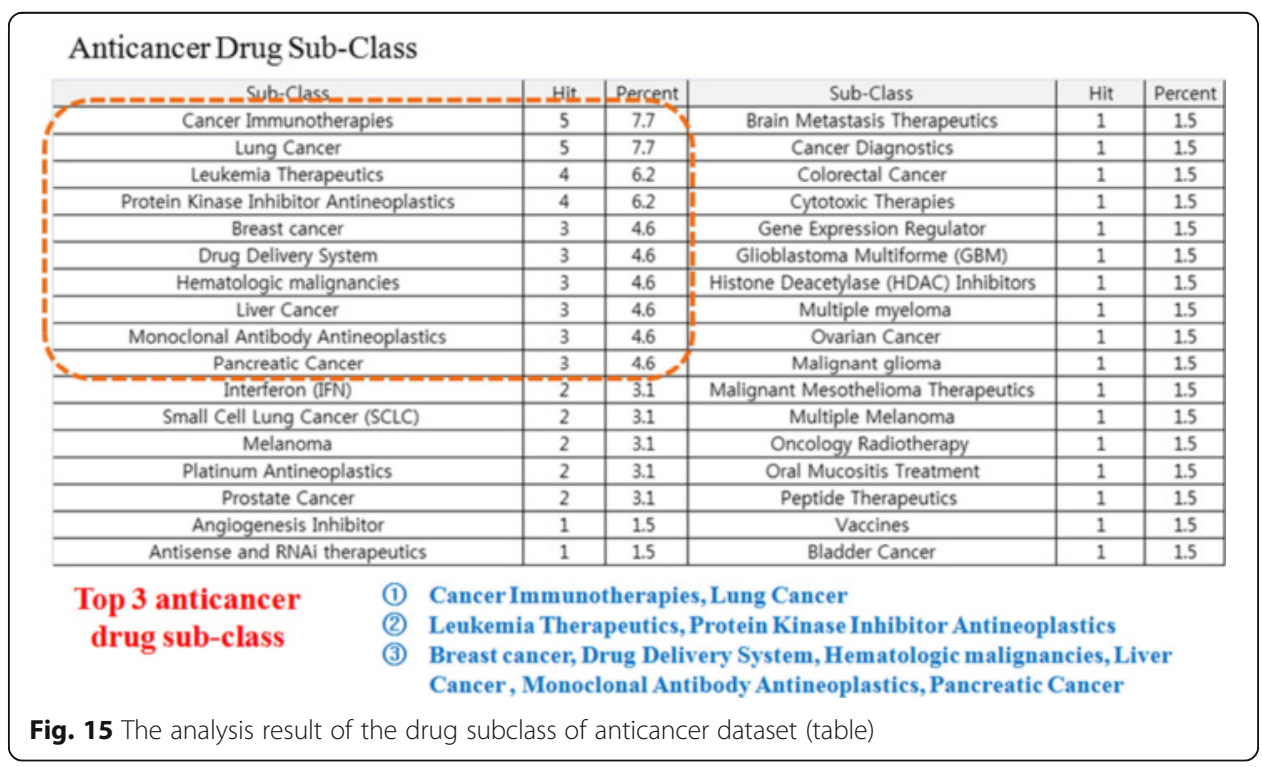




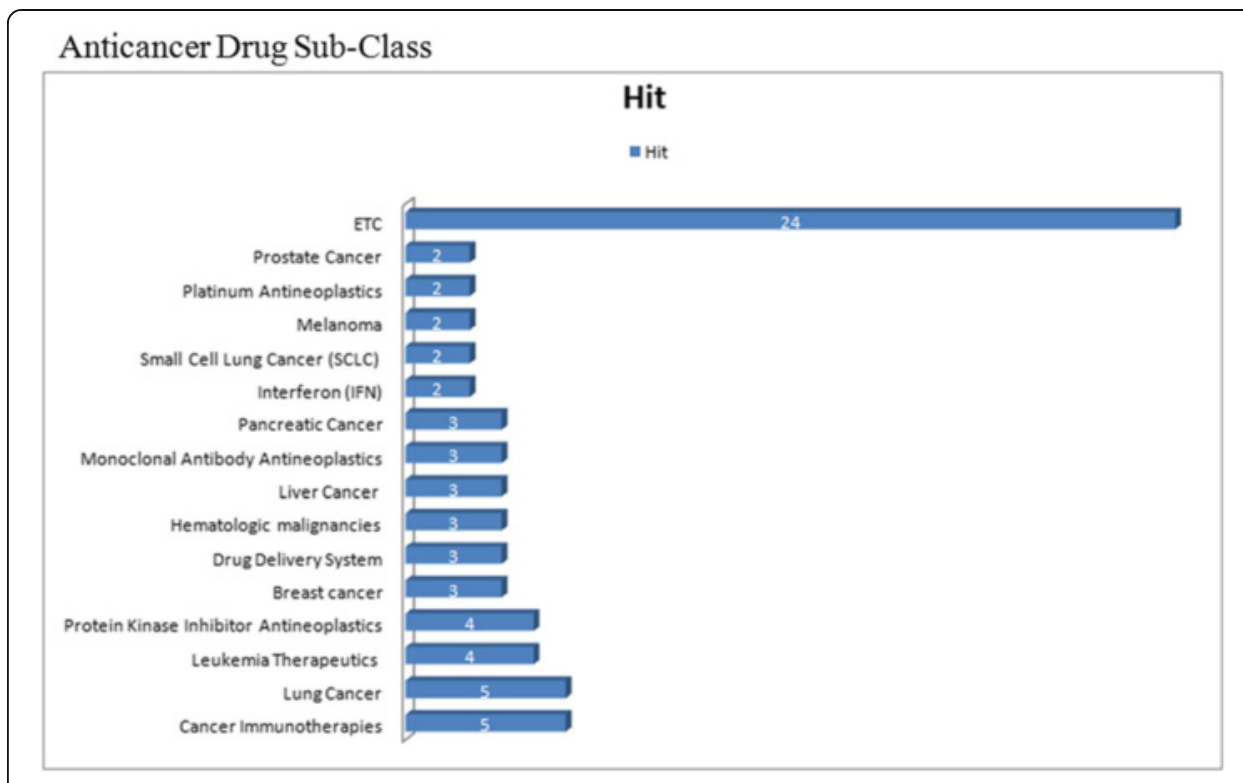

Fig. 16 The analysis result of the drug subclass of anticancer dataset (graph)

\begin{tabular}{|c|c|c|c|}
\hline & Subclass contents & $\begin{array}{l}\text { \# of } \\
\text { Hit } \\
\end{array}$ & $\begin{array}{l}\text { TCT } \\
\text { (Year) }\end{array}$ \\
\hline A61k & PREPARATIONS FOR MEDICAL, DENTAL, OR TOILET PURPOSES & 109 & 8 \\
\hline C07D & HETEROCYCLIC COMPOUNDS & 14 & 7 \\
\hline A61P & $\begin{array}{l}\text { SPECIFIC THERAPEUTIC ACTMTYY OF CHEMICAL COMPOUNDS OR MEDICINAL PREPARATO } \\
\text { NS }\end{array}$ & 13 & 3 \\
\hline c07k & PEPTIDES & 9 & 7 \\
\hline & $\begin{array}{l}\text { MICRO-ORGANISMS OR ENZYMES; COMPOSIIIONS THEREOF ; PROPAGATING, PRESERVIN } \\
\text { G, OR MAINTAINING MICRO-ORGANISMS; MUTATION OR GENETIC ENGINEERING; CULTU } \\
\text { REMEDIA }\end{array}$ & 8 & 8 \\
\hline Go1N & $\begin{array}{l}\text { INVESTIGATING OR ANALYSING MATERIALS BY DETERMINING THERR CHEMICAL OR PHYSI } \\
\text { CAL PROPERTIES }\end{array}$ & 7 & 9 \\
\hline $\mathrm{CO} \mathrm{H}$ & SUGARS; DERIVATIVES THEREOF; NUCLEOSIDES; NUCLEOTIDES; NUCLEIC ACIDS & 6 & 9 \\
\hline $\mathrm{C} 12 \mathrm{Q}$ & $\begin{array}{l}\text { MEASURING OR TESTING PROCESSES INVOLVING ENZYMES OR MICRO-ORGANISMS; COM } \\
\text { POSIIIONS OR TEST PAPERS THEREFOR; PROCESSES OF PREPARING SUCH COMPOSIIONS } \\
\text { : CONDITION-RESPONSINE CONTROL IN MICROBIOLOGICAL OR ENZYMOLOGICAL PROCES } \\
\text { SES }\end{array}$ & 5 & 7 \\
\hline $\mathrm{A} 01 \mathrm{~N}$ & $\begin{array}{l}\text { PRESERVATION OF BODIES OF HUMANS OR ANIMALS OR PLANTS OR PARTS THEREOF; BI } \\
\text { OCIDES, e.g. AS DISINFECTANTS, AS PESTICIDES OR AS HERBICIDES }\end{array}$ & 4 & 8 \\
\hline $\mathrm{cotc}$ & ACYCLIC OR CARBOCYCUC COMPOUNDS & 3 & 9 \\
\hline C12P & $\begin{array}{l}\text { FERMENTATION OR ENZYME-USING PROCESSES TO SYNTHESISE A DESIRED CHEMICALC } \\
\text { OMPOUND OR COMPOSMION OR TO SEPARATE OPTICAL ISOMERS FROM A RACEMIC MI } \\
\text { XTURE }\end{array}$ & 3 & 7 \\
\hline $\mathrm{A} 61 \mathrm{M}$ & $\begin{array}{l}\text { DEVCES FOR INTRODUCING MEDIA INTO, OR ONTO, THE BODY; DEVCES FOR TRANSDU } \\
\text { CING BODY MEDIA OR FOR TAKING MEDIA FROM THE BODY; DEVICES FOR PRODUCING } \\
\text { OR ENDING SLEEP OR STUPOR }\end{array}$ & 2 & 10 \\
\hline CO7F & $\begin{array}{l}\text { ACYCLC, CARBOCYCLC, OR HETEROCYCLC COMPOUNDS CONTAINING ELEMENTS OTHER } \\
\text { THAN CARBON, HYDROGEN, HALOGEN, OXYGEN, NITROGEN, SULFUR, SELENIUM OR TELI } \\
\text { URIUM }\end{array}$ & 2 & 7 \\
\hline A01K & $\begin{array}{l}\text { ANIMAL HUSBANDRY; CARE OF BIRDS, FISHES, INSECTS; FISHING; REARING OR BREEDING } \\
\text { ANIMALS, NOT OTHERWISE PROVIDED FOR; NEW BREEDS OF ANIMALS }\end{array}$ & 1 & 11 \\
\hline A61N & ELECTROTHERAPY; MAGNETOTHERAPY; RADIATION THERAPY; ULTRASOUND THERAPY & 1 & 8 \\
\hline A61Q & SPECIFIC USE OF COSMETICS OR SIMILAR TOILET PREPARATIONS & 1 & 2 \\
\hline $\operatorname{cosk}$ & $\begin{array}{l}\text { MATERIALS FOR APPLICATIONS NOT OTHERWISE PROVDED FOR; APPLICATONS OF MATE } \\
\text { RIALS NOT OTHERWISE PROVDED FOR }\end{array}$ & 1 & 7 \\
\hline CO7B & GENERAL METHODS OF ORGANIC CHEMISTRY; APPARATUS THEREFOR & 1 & 4 \\
\hline
\end{tabular}

Fig. 17 The analysis result of IPC code in the corresponding patent in the licensing deal 


\section{OR MEDICINAL PREPARATIONS (A61P) (4) PEPTIDES (C07K) (5) MICRO- ORGANISMS OR ENZYMES (C12N).}

Figures 18 and 19 show the analysis of Market size of Anticancer Drug Subclass of anticancer drug dataset. As shown in Fig. 18, top 5 market in the market size is as follows: (1) Drug Delivery System (2) Hematologic malignancies (3) Monoclonal Antibody Antineoplastics (4) Ovarian Cancer (5) Peptide Therapeutics.

Figure 20 shows the analysis of Licensee (license buyer) Revenue of anticancer drug dataset. The interesting point we found is small-medium companies occupied $66 \%$ in the licensee percent. The percent of small-medium companies to participate in the licensing deals is bigger than the one of the big companies.

Figure 21 shows the analysis of Development phase distribution of anticancer drug dataset that reported in our previous paper (Lee et al. 2016). As show in Fig. 21, Phase 2-related stage deals occupied over $43 \%$.

\section{Regression analysis}

\section{Regression analysis of anticancer (antineoplastics) dataset}

We investigated the relationship between multiple independent variables of the attrition rate for the development phase, market size, CAGR, TCT median value for the IPC code (IP), and the revenue data of the license buyer and the dependent variable of back-end payment (running royalty rate); its graph is as shown in Fig. 22, and its prediction formula follows Eq. 1. We found that regression model is statistically meaningful at the significance level of $1 \%$ (P-Value: 0.001$)$.

\begin{tabular}{|c|c|c|c|}
\hline \multicolumn{2}{|c|}{ Market size of Anticancer Drug Sub-Class } & \multicolumn{2}{|c|}{ Top 5 Market in Anticancer drug class } \\
\hline Sub-Class & Estimated Market Size (MS, 2015) & Sub-Class & Estimated Market Size (MS, 2015) \\
\hline Drug Delivery System & 388,652 & Cancer Diagnostics & 7,100 \\
\hline Hematologic malignancies & 30,700 & Oncology Radiotherapy & 5,585 \\
\hline $\begin{array}{l}\text { Monoclonal Antibody Antineopla } \\
\text { stics }\end{array}$ & 24,312 & Vaccines & 4,744 \\
\hline Ovarian Cancer & 23,148 & Gene Expression Regulator & 3,390 \\
\hline Peptide Therapeutics & 19,973 & Prostate Cancer & 3,285 \\
\hline $\begin{array}{l}\text { Protein Kinase Inhibitor Antineop } \\
\text { lastics }\end{array}$ & 17,570 & Cancer Immunotherapies & 2,800 \\
\hline Cytotoxic Therapies & 13,389 & Colorectal Cancer & 2,433 \\
\hline Breast Cancer & 11,159 & Melanoma & 1,788 \\
\hline Interferon (IFN) & 10,000 & Malignant glioma & 1,786 \\
\hline Leukemia Therapeutics & 8,574 & Angiogenesis Inhibitor & 1,656 \\
\hline Multiple Melanoma & 7,636 & Platinum Antineoplastics & 1,496 \\
\hline Lung Cancer & 7,487 & Antisense and RNAi therapeutics & 1,114 \\
\hline Oral Mucositis Treatment & 1,048 & Glioblastoma Multiforme (GBM) & 379 \\
\hline Pancreatic cancer & 1,038 & Brain Metastasis Therapeutics & 374 \\
\hline TARCEVA & 1,024 & Bladder Cancer Therapeutics & 273 \\
\hline Liver Canacer Therapeutics & 821 & Small Cell Lung Cancer (SCLC) & 253 \\
\hline Photomedicine & 661 & $\begin{array}{c}\text { Malignant Mesothelioma Therap } \\
\text { eutics }\end{array}$ & 202 \\
\hline $\begin{array}{l}\text { Histone Deacetylase (HDAC) Inhi } \\
\text { bitors }\end{array}$ & 399 & & \\
\hline
\end{tabular}




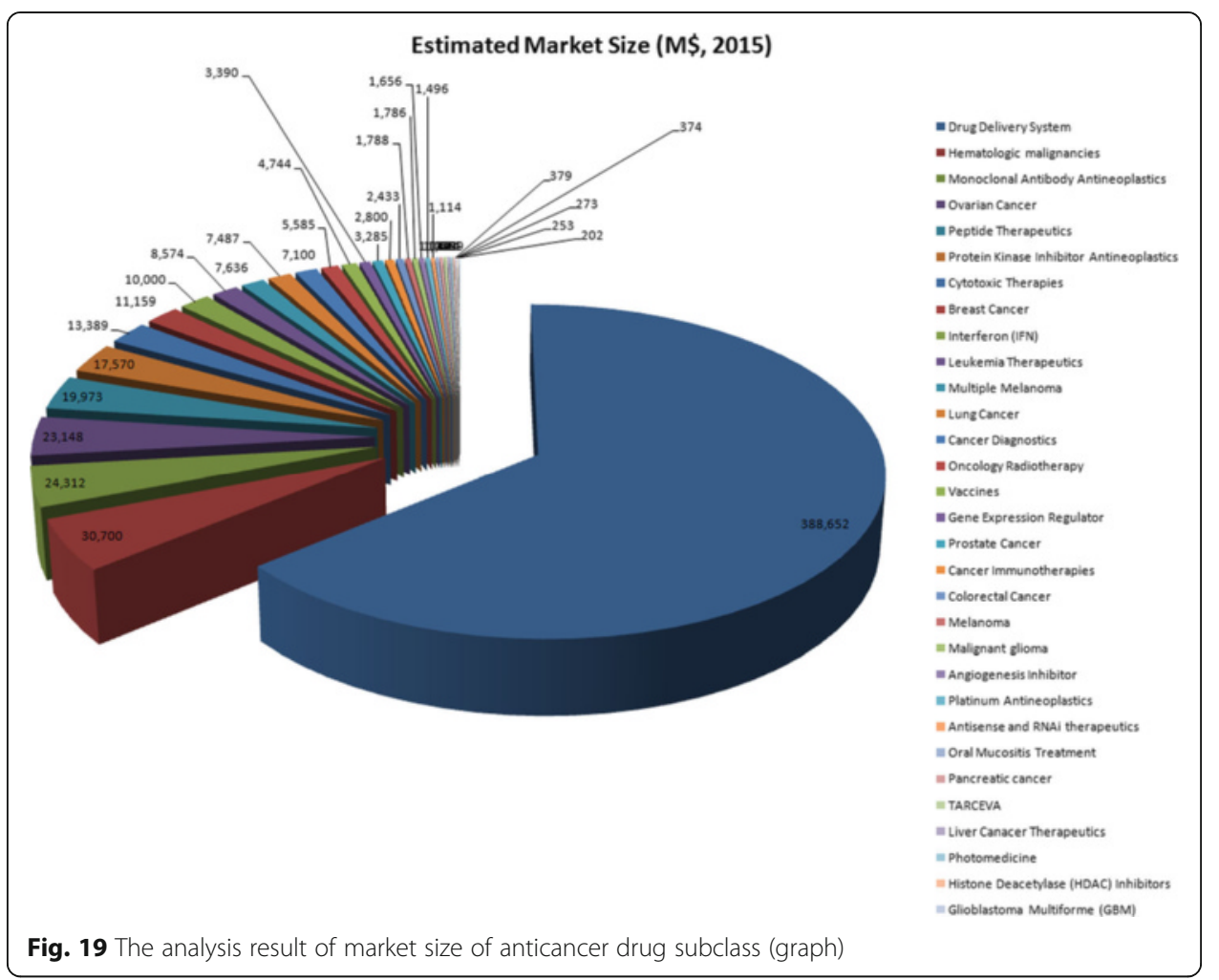

Royalty Rate $=9.997+0.063 *$ Attrition Rate $+1.655 *$ Licensee Revenue $-0.410 *$ TCT Median-1.090* Market Size-0.230* CAGR

$P$-Value $=0.001$

Independent Variables = multiple independent variables of the attrition rate for the development phase, market size, CAGR, TCT median value for the IPC code (IP), and the revenue data of the license buyer.

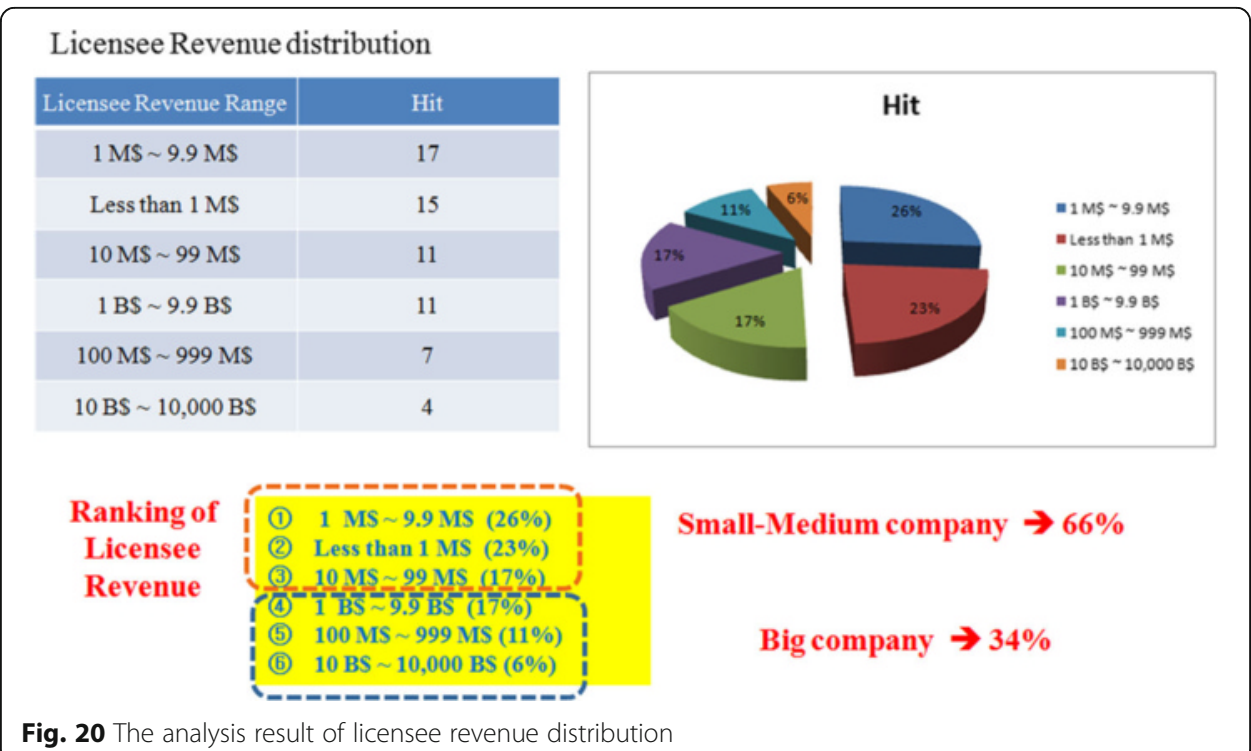




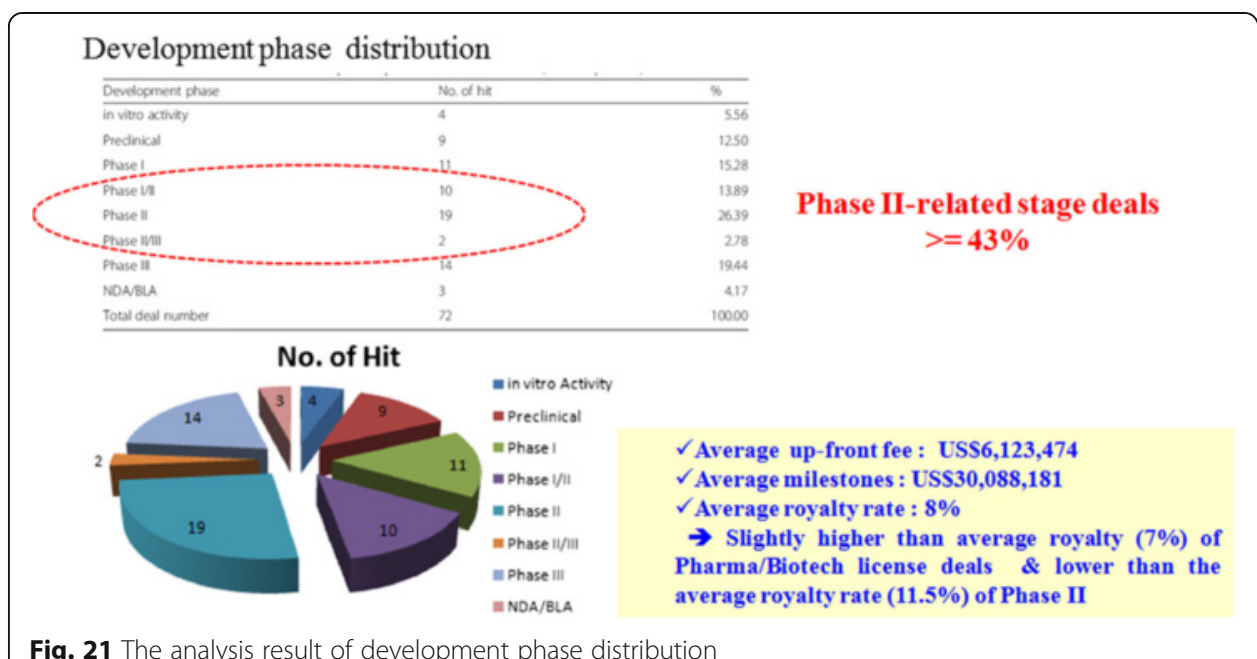

Dependent Variable $=$ Royalty rates [Unit: USD] Fig. 23.

As shown in Fig. 24, Licensee Revenue is statistically meaningful and has significant positive influence at the significance level of $5 \%$. The most significant variables affected is Licensee Revenue, because Licensee Revenue has the biggest B-Value. Ranking of factors that influence the royalty rate is as follows: (1) Licensee Revenue (+) (2) Market

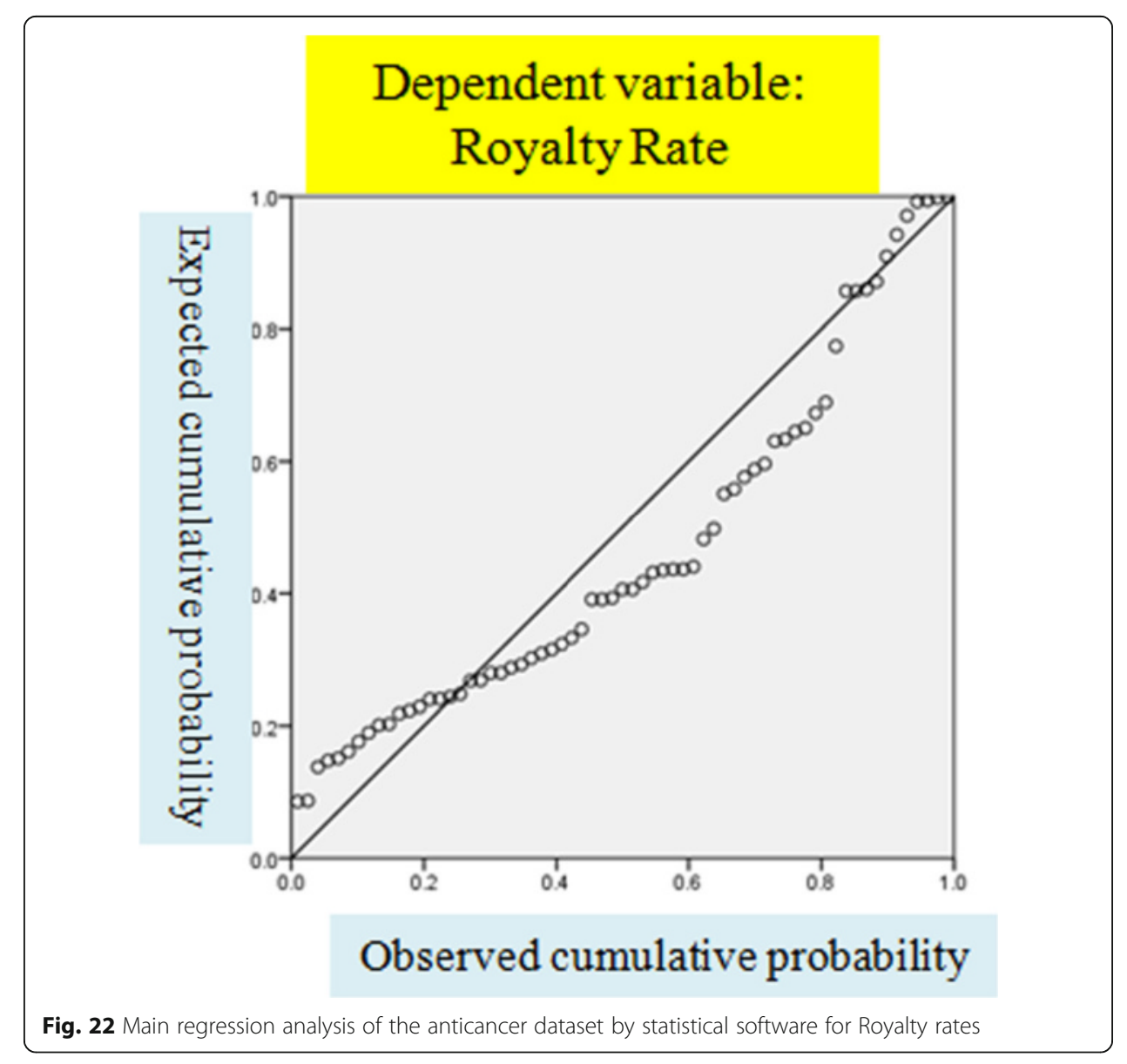




\begin{tabular}{|c|c|c|c|c|c|}
\hline Model & $\begin{array}{c}\text { Sum of } \\
\text { squares }\end{array}$ & $\begin{array}{c}\text { Degrees of } \\
\text { freedom }\end{array}$ & $\begin{array}{c}\text { Mean } \\
\text { Squares }\end{array}$ & F & P-Value \\
\hline $\begin{array}{c}\text { Regression } \\
\text { Model }\end{array}$ & 1067.746 & 5 & 213.549 & 4.519 & $\mathbf{0 . 0 0 1}$ \\
\hline Residual & 2787.873 & 59 & 47.252 & \\
\hline Sum & 3855.619 & 64 & \\
\hline Fitted Values: (Constant), CAGR, Licensee Revenue, Attrition Rate, TCT median \\
\hline
\end{tabular}

Fig. 23 The summary of statistical characteristics of proposed regression model for estimating royalty rates

Size (-) (3) TCT median value (-) (4) CAGR (-) (5) Attrition Rate (+). Plus (+) symbol means positive influences and Negative $(-)$ symbol means negative influences. CAGR is statistically meaningful and has significant negative influence at the significance level of $1 \%$. Attrition Rate, TCT median value, Market Size are not significantly meaningful.

We investigated the relationship between multiple independent variables of the attrition rate for the development phase, market size, CAGR, TCT median value for the IPC code (IP), and the revenue data of the license buyer and the dependent variable of back-end payment (running royalty rate); its graph is as shown in Fig. 25, and its prediction formula follows Eq. 2 . We found that the regression model is statistically not meaningful ( $P$-Value: 0.288$)$, thus requiring further study.

Up-Front Payment $($ Up-front + Milestones $)=2.909-0.006 *$ Attrition Rate $+0.306 \mathrm{~s}$ * Licensee Revenue-0.74* TCT Median-0.113* Market Size-0.009* CAGR

$P$-Value $=0.288$

Independent Variables = multiple independent variables of the attrition rate for the development phase, market size, CAGR, TCT median value for the IPC code (IP), and the revenue data of the license buyer

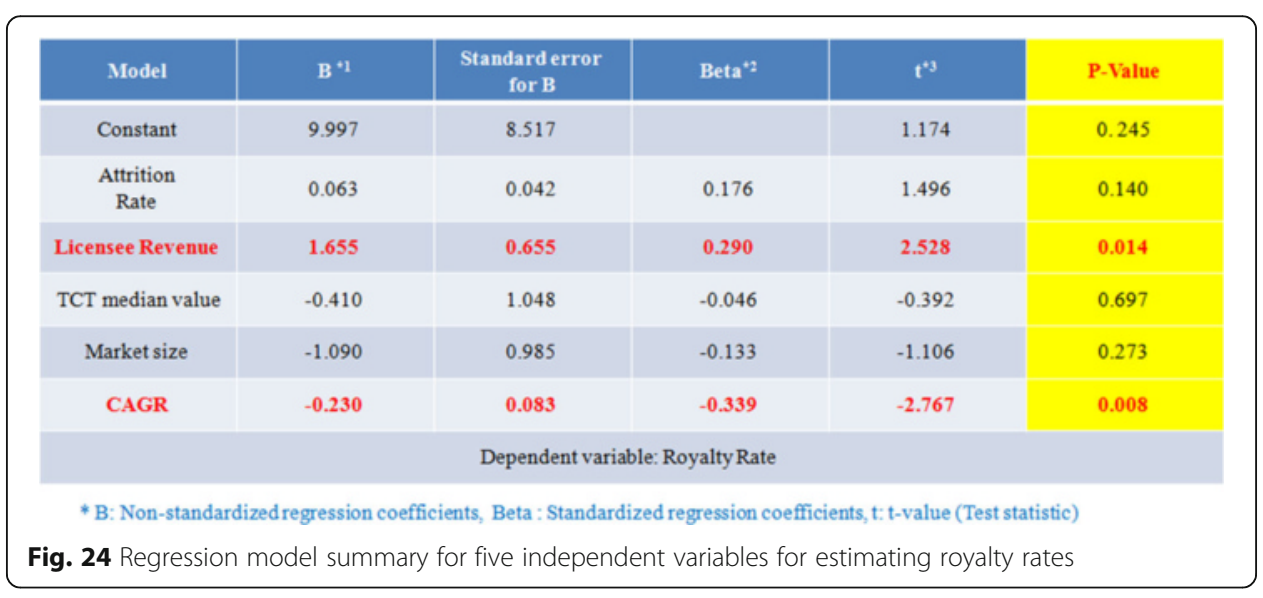




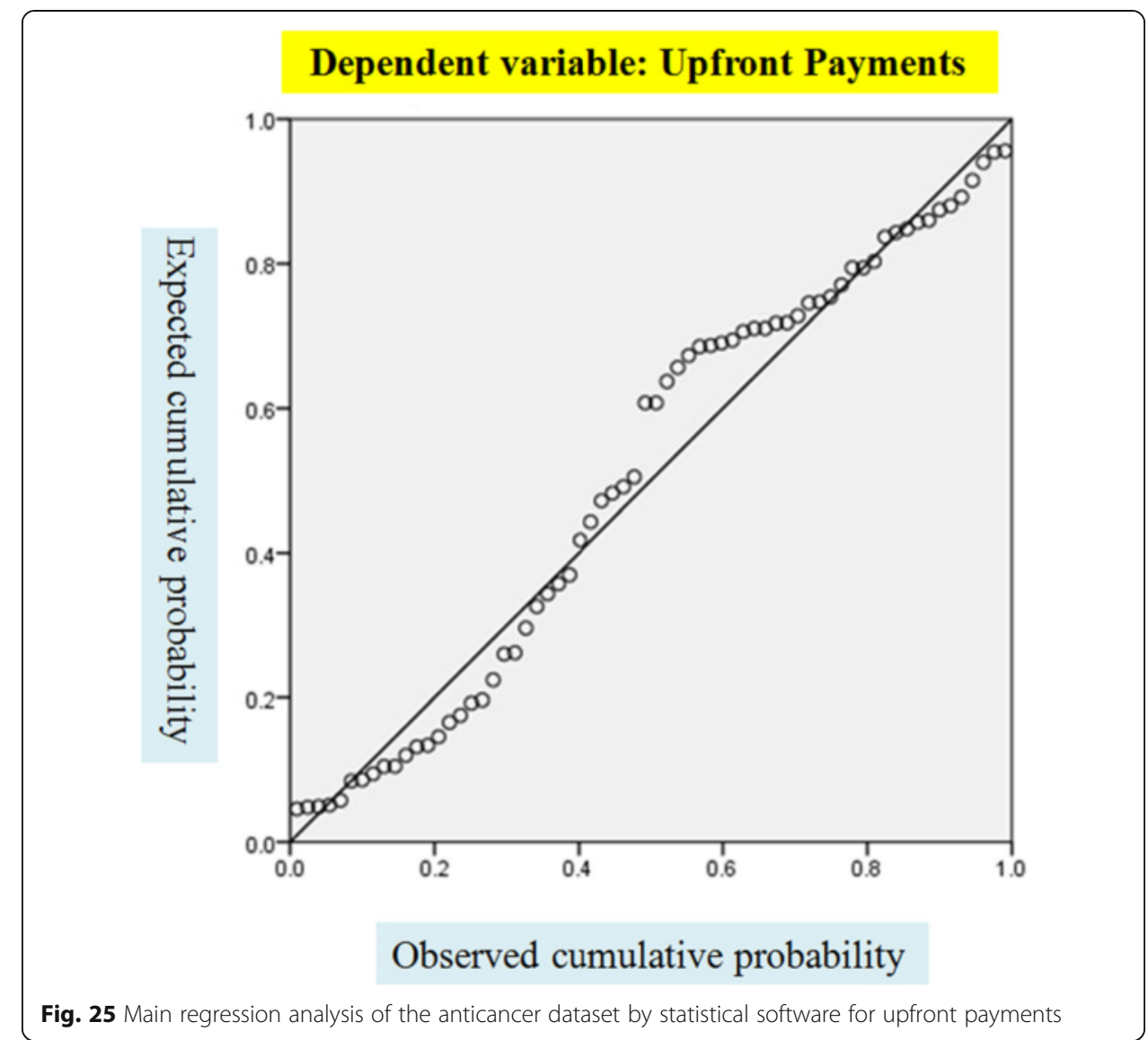

Dependent Variable $=$ up-front payment (up-front fee + milestones) [Unit: USD] Fig. 26

As shown in Fig. 27, Licensee Revenue is statistically meaningful and has significant positive influence at the significance level of $5 \%$. The most significant variables affected is Licensee Revenue, because Licensee Revenue has the biggest B-Value. Ranking of factors that influence the up-front payments is as follows: (1) Licensee Revenue (+) (2) Market Size (-) (3) TCT median value (-) (4) CAGR (-) (5) Attrition Rate (-).Plus (+) symbol means positive influences and Negative $(-)$ symbol means negative influences. However, the regression model is statistically not meaningful ( $P$-Value: 0.288 ).

\begin{tabular}{|c|c|c|c|c|c|}
\hline Model & Sum of squares & $\begin{array}{l}\text { Degrees of } \\
\text { freedom }\end{array}$ & Mean Squares & $\mathbf{F}$ & P-Value \\
\hline $\begin{array}{c}\text { Regression } \\
\text { Model }\end{array}$ & 12.112 & 5 & 2.422 & 1.271 & 0.288 \\
\hline Residual & 114.373 & 60 & 1.906 & & \\
\hline Sum & 126.485 & 65 & & & \\
\hline \multicolumn{6}{|c|}{ Dependent variable: Upfront Payment } \\
\hline Fitted V & s: (Constant), CA & icensee Rev & e, Attrition Rate, I & dian v & t Size \\
\hline
\end{tabular}




\begin{tabular}{|c|c|c|c|c|c|}
\hline Model & $B^{* 1}$ & $\begin{array}{c}\text { Standard error } \\
\text { for B } \\
\end{array}$ & Beta $^{\prime 2}$ & $t^{* 3}$ & P-Value \\
\hline Constant & 2.909 & 1.711 & & 1.701 & 0.245 \\
\hline $\begin{array}{l}\text { Attrition } \\
\text { Rate }\end{array}$ & -0.006 & 0.008 & -0.091 & -0.701 & 0.486 \\
\hline Licensee Revenue & 0.306 & 0.129 & 0.298 & 2.369 & 0.021 \\
\hline TCT median value & -0.074 & 0.210 & -0.046 & -0.351 & 0.727 \\
\hline Market size & -0.113 & 0.192 & -0.076 & -0.585 & 0.560 \\
\hline CAGR & -0.009 & 0.016 & -0.076 & -0.564 & 0.575 \\
\hline \multicolumn{6}{|c|}{ Dependent variable: Royalty Rate } \\
\hline
\end{tabular}

Fig. 27 Regression model summary for five independent variables for estimating up-front payments

\section{Discussion}

A regression analysis was carried out to estimate up-front payments and royalty rates for one dataset of anticancer (antineoplastics) drug classes. In the case of the prediction of Royalty rates, the models for predicting having a $P$-value of 0.001 for the anticancer (antineoplastics) dataset was obtained through statistical analyses. In case of the prediction of royalty rates, the models for predicting having a $P$-value of 0.288 for the anticancer (antineoplastics) dataset was obtained through statistical analyses. Figure 28 shows the overview of the process of this study.

This study was presented with many limitations to reasonably determine the variables for prediction because up-front payments and royalty rates are determined by highly various environmental variables in the field. However, this study developed a prediction model like Eq. 1 having a $P$-value of 0.001 for estimating royalty rates if multiple independent variable like the attrition rate for the development phase, market size, CAGR, TCT median value for the IPC code (IP), and the revenue data of the license buyer are used. This is a "statistically significant" finding at the significance level of $1 \%$ ( $P$-Value: 0.001). Thus, the said variables can be used as the solid basis for evaluating royalty rates in the future. Ranking of factors that influence the royalty rate is as follows: (1) Licensee Revenue (+) (2) Market Size (-) (3) TCT median value (-) (4) CAGR (-) (5) Attrition Rate $(+)$. In the regression model to predict the royalty rate, Royalty Rate is in direct proportion to Licensee Revenue and Attrition Rate and Royalty Rate is reverse proportion to Market Size, TCT median value and CAGR.

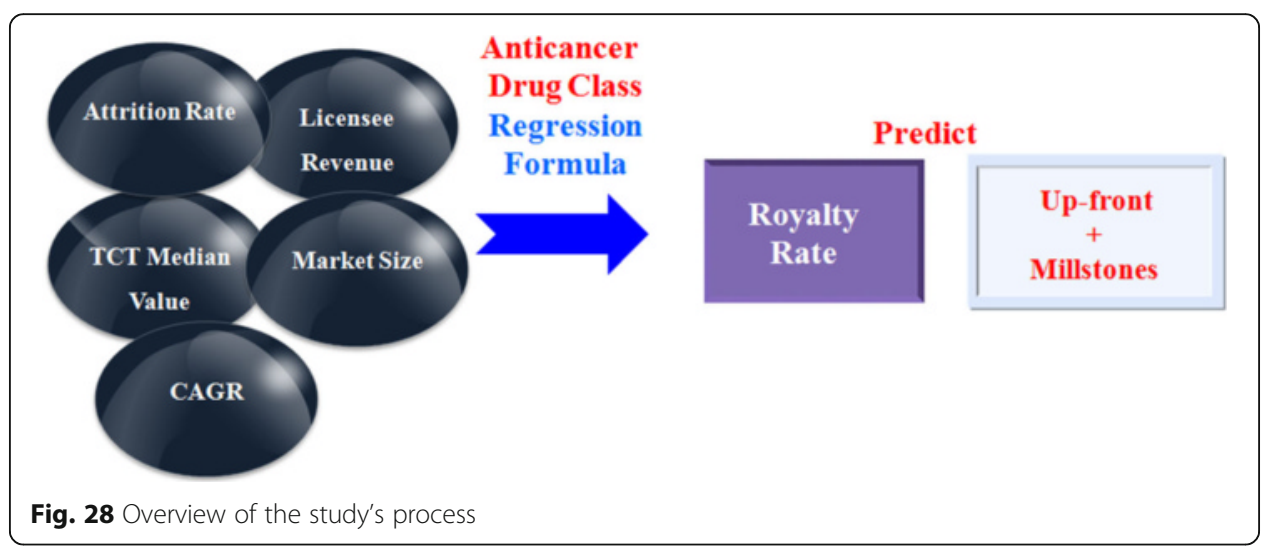


Royalty Rate $=9.997+0.063 *$ Attrition Rate $+1.655 *$ Licensee Revenue $-0.410 *$ TCT Median $-1.090 *$ Market Size $-0.230 *$ CAGR (Eq. 1)

In the case of the prediction of up-front payments, this study developed a prediction model like Eq. 2 having a $P$-value of 0.288 for estimating up-front payments if multiple independent variable like the attrition rate for the development phase, market size, CAGR, TCT median value for the IPC code (IP), and the revenue data of the license buyer are used. This is a "statistically not meaningful" finding. Thus, the above prediction model for up-front payments requires further study. Ranking of factors that influence the up-front payments is as follows: (1) Licensee Revenue (+) (2) Market Size (-) (3) TCT median value (-) (4) CAGR (-) (5) Attrition Rate (-). In the regression model to predict the up-front payment, Up-front payments is in direct proportion to Licensee Revenue and Up-front payments is reverse proportion to Market Size, TCT median value, CAGR and Attrition rate.

Up-front Payment (Up-front + Milestones) $=2.909-0.006 *$ Attrition Rate +0.306

* Licensee Revenue $-0.74 *$ TCT Median $-0.113 *$ Market Size $-0.009 *$ CAGR (Eq. 2)

\section{Conclusion}

In royalty negotiations in the life sciences sector, a manager needs a simple tool to estimate the proper royalty rate and up-front payment. Indeed, developing the right valuation methods is very important for the pharmaceutical company, which wants licensing and M\&A (Lee et al. 2016). It is also the reason why many pharmaceutical companies keep their valuation know-how secret. This exclusivity sometimes hinders brisk licensing and M\&A activities. Therefore, developing and sharing the right valuation methods cannot help one specific company's licensing and M\&A but can also help the development of licensing and M\&A market itself. It related to realizing the merit of the open innovation, which assumes that sharing ideas can be advantageous for all players (Jeon et al. 2015; Leydesdorf \& Ivanova, 2016; Oganisjana, 2015; Yun et al. 2016). For this purpose, we proposed the valuation tools.

First, this study yielded meaningful results to predict the royalty rate by the regression analysis using multiple input descriptors. But in the case of the prediction of upfront payments, it requires further study. This study provides the insight what would be the most determining factors to get appropriate license fee among several multiple factors like development phase, market size of subclass of a drug class, TCT median value (Technology Cycle Time) of IP, and the revenue data of the license buyer which can be expressed in numeric form.

Second, This study yielded meaningful results as it aimed to create a tool to predict royalty rate using knowledge on the development phase and its attrition rate, drug class, TCT median value (Technology Cycle Time) median value for the IPC code (IP) of the IP, Market size of the technology, CAGR (Compound Annual Growth Rate) of the corresponding market and licensee's revenue, which can easily be Known.

This study covers only one drug class of anticancer and will be extended to cover more drug classes in the future.

\section{Implications}

Valuation of drug specific to drug class can be possible and the royalty rate is in direct proportion to licensee revenue and attrition Rate and is in inverse proportion to Market Size, TCT median value and CAGR in specific drug class. 


\section{Topics for further research}

Further in-depth research is necessary for the following topics in the future.

1. The relationship for other drug classes and royalty related data regression analysis using multiple input descriptors.

2. The comparison of the estimation results between by using the prediction formula derived regression analysis Vs. by using traditional valuation methods like e-NPV or Real Options.

\section{Acknowledgments}

We would like to show our gratitude to Dr. Kee Heon Cho of Korea Valuation Association and Dr. Tae-Eung Sung and Dr. Sang-Kuk Kim of KISTI for their guidance, and to KISTI for the data source provided.

\section{Authors' contributions}

$J \mathrm{HL}$ primarily worked on the research. BKS, JWL, YI and WL participated in the design of the research and helped to perform the statistical analysis. TK conceived of the research and participated in its design and coordination as the corresponding author. All authors read and approved the final manuscript.

\section{Competing interests}

The authors declare that they have no competing interests.

\section{Author details}

${ }^{1}$ Patent Law Firm WELL (WELL), 4F Daemyung Building shingwan, 205 Bangbae-ro, Seocho-gu, Seoul 06562, South Korea. ${ }^{2}$ School of Business, Chungbuk National University, 1 Chungdae-ro, Seoweon-gu, Cheong-Ju, Chungbuk 28644, South Korea. ${ }^{3}$ Korea Institute of Science and Technology Information (KISTI), Hoegi-ro, 66, Dongdemun-gu, Seoul 130-741, South Korea. ${ }^{\circ}$ Digital Science Co., Ltd (DS), \# 304, 3 F, Kumkang B/D, 71 Garak-ro, Songpa-gu, Seoul 138-846, South Korea. ${ }^{5}$ KMA Consultants Inc, 8F, 101 Yeouigongwonro, Youngdeungpo-gu, Seoul 02741, South Korea.

Received: 13 July 2016 Accepted: 5 October 2016

Published online: 17 October 2016

\section{References}

Arnold, K., Coia, A., Saywell, S., Smith, T., Minick, S., \& Löffler, A. (2002). Value drivers in licensing deals. Nat Biotechnol., 20, 1085-9.

Bogdan, B., \& Villiger, R. (2010). Valuation in life sciences - a practical guide (3rd ed.). New York: Springer.

Carte, N. (2005). The maximum achievable profit method of patent valuation. International Journal of Innovation and Technology Management, 02(02), 135-151.

Deloitte Centre for Health Solutions (2015). 2015 Global life sciences outlook: Adapting in an era of transformation. https://www2.deloitte.com/content/dam/Deloitte/global/Documents/Life-Sciences-Health-Care/gx-Ishc-2015-lifesciences-report.pdf. Accessed 22 Jun 2016.

DiMasi, J. A., Grabowski, H. G., \& Hansen, R. W. (2016). Innovation in the pharmaceutical industry: new estimates of R\&D costs. Journal of Health Economics, 47, 20-33.

Ernst, H., Legler, S., \& Lichtenthaler, U. (2010). Determinants of patent value: Insights from a simulation analysis. Technological Forecasting and Social Change, 77(1), 1-19.

Hu, X., Rousseau, R., \& Chen, J. (2012). A new approach for measuring the value of patents based on structural indicators for ego patent citation networks. Journal of the American Society for Information Science and Technology, 63(9), 1834-1842.

Hu, Y., Scherngell, T., Man, S. N., \& Wang, Y. (2008). Opening the black box of pharmaceutical patent value: An empirical analysis. Drug Information Journal, 42(6), 561-568.

Jeon, J., Kim, S., \& Koh, J. (2015). Historical review on the patterns of open innovation at the national level: the case of the roman period. Journal of Open Innovation: Technology, Market, and Complexity, 1(20), 1-17.

Kaitin, K. (2015). Pushing the innovation envelope: Strategies for boosting productivity and ROI. Evolution Summit 2015, Tufts University School of Medicine.

Kim, S.-J. (2016). The effect of service innovation on R\&D activities and government support systems: The moderating role of government support systems in Korea. Journal of Open Innovation: Technology, Market, and Complexity, 2(5), 1-13.

Lee, J. H., In, Y., Lee, I.-H., \& Lee, J. W. (2016). Valuations using royalty data in the life sciences area-focused on anticancer and cardiovascular therapies. Journal of Open Innovation: Technology, Market, and Complexity, 2(1), 1-25.

Leydesdorf, L., \& Ivanova, I. (2016). "Open innovation" and "triple helix" models of innovation: can synergy in innovation systems be measured? Journal of Open Innovation: Technology, Market, and Complexity, 2(11),1-12.

Nair, S. S., Mathew, M., \& Nag, D. (2012). Effect of firm variables on patent price. IIMB Management Review, 24(1), 40-47.

Nigel Borshell, N., \& Ahmed, T. (Eds.). (2012). Approaches to valuation of pharmaceutical licensing deals, PharmaVentures. http://files.pharmadeals.net/contents/Sample_Valuation.pdf. Accessed 22 Jun 201

Oganisjana, K. (2015). Promotion of university students' collaborative skills in open innovation environment. Journal of Open Innovation: Technology, Market, and Complexity, 1(20),1-17.

Patra, S. K., \& Krishna, V. V. (2015). Globalization of R\&D and open innovation: Linkages of foreign R\&D centers in India. Journal of Open Innovation: Technology, Market, and Complexity, 1(7),1-24. 
Pullan, L. (2014). Valuation of your early drug candidate. White Paper, ShareVault.

Ranade, V. (2008). Early-Stage Valuation in the Biotechnology Industry. Shorenstein ASIA-PACIFIC RESEARCH CENTER, https://www.ciaonet.org/attachments/691/uploads. Accessed 22 Jun 2016.

Schwartz, E. S. (2004). Patents and R\&D as real options. Economic Notes by Banca Monte dei Paschi di Siena SpA, 33(1), 23-54.

Suh, J. H. (2015). Exploring the effect of structural patent indicators in forward patent citation networks on patent price from firm market value. Technology Analysis \& Strategic Management, 27(5), 485-502.

Young, P. (2016). Biotech financial and M\&A trends-two steps forward, one step back. Pharmaceutical Executive, http://www.pharmexec.com/biotech-financial-and-ma-trends-two-steps-forward-one-step-back. Accessed 22 Jun 2016.

Yun, J. J., Won, D. K., \& Park, K. (2016). Dynamics from open innovation to evolutionary change. Journal of Open Innovation: Technology, Market, and Complexity, 2(7),1-22.

\section{Submit your manuscript to a SpringerOpen ${ }^{\circ}$ journal and benefit from:}

- Convenient online submission

- Rigorous peer review

- Immediate publication on acceptance

- Open access: articles freely available online

- High visibility within the field

- Retaining the copyright to your article

Submit your next manuscript at $\boldsymbol{\nabla}$ springeropen.com 